Portland State University

PDXScholar

Engineering and Technology Management

Faculty Publications and Presentations

8-1-2015

\title{
A Study of the U.S. Intrastate Crowdfunding Exemptions
}

Ahmed Bohliqa

Portland State University

Follow this and additional works at: https://pdxscholar.library.pdx.edu/etm_fac

Part of the Operations Research, Systems Engineering and Industrial Engineering Commons

Let us know how access to this document benefits you.

\section{Citation Details}

Bohliqa, A. (2015, August). A study of the US intrastate crowdfunding exemptions. In Management of Engineering and Technology (PICMET), 2015 Portland International Conference on (pp. 961-967). IEEE.

This Article is brought to you for free and open access. It has been accepted for inclusion in Engineering and Technology Management Faculty Publications and Presentations by an authorized administrator of PDXScholar. Please contact us if we can make this document more accessible: pdxscholar@pdx.edu. 


\title{
A Study of the U.S. Intrastate Crowdfunding Exemptions
}

\author{
Ahmed Bohliqa \\ Dept. of Engineering and Technology Management, Portland State University, Portland, OR - USA
}

\begin{abstract}
The enactment of intrastate crowdfunding exemptions around the United States has built up a lot of excitement. Crowdfunding became a popular phenomenon in the past 15 years for art and design projects. Crowdfunding companies only allowed raising money by receiving donations or loans without giving funders any security interests in the project's company. This is because any potential economic return could turn the transaction into a securities offering subject to the costly federal and state laws and regulations. Nonetheless, crowdfunding has been effective in enabling new innovations and ideas bloom. Intrastate securities crowdfunding might prove to be one of the most rewarding and game changing financial movements in the United States. It will strengthen the local economy represented by small businesses and help launch innovative new startups. However, its unique position between non-securities-based crowdfunding and private equity investments introduces complexity that must be mitigated before rewards can be harnesses. The paper analyzes this complexity by breaking it down into advantages and disadvantages. Each potential advantage and disadvantage is discussed and recommendations are made. Recommendations will be found useful for technology managers, technology entrepreneurs, organizations and agencies that plan to provide technical business services to entrepreneurs and small businesses, as well as advocates and regulators.
\end{abstract}

\section{INTRODUCTION}

\section{A. Intrastate Crowdfunding Exemptions}

A lot of excitement has built up recently with the enactment of intrastate crowdfunding exemptions around the United States. There are currently exceptions available in 17 states and another 14 states are in various stages [1]. Refer to table 1 for summary. Many of the recent news articles refer these exemptions as a reaction to the Securities and Exchange Commission (SEC) delay in regulating the Jumpstart Our Business Startups (JOBS) Act, which was signed into law on April 5, 2012 by President Barack Obama. The goal of this Act is to allow an alternative of raising capital for companies through the crowd, particularly Title III of the Act, which is titled Crowdfund Act [2]. However, what is commonly not mentioned is that the consideration of crowdfunding as a financing alternative was a reaction to the 2008 financial crisis [3]. Back then there was the microfinance movement, which extended to charities and then evolved to support artists and to finance innovative products. As a matter of fact, the needs of a financing alternative has driven some states to enact their own intrastate crowdfunding exemptions even before the JOBS Act was signed into law; the states of Kansas, Georgia and Idaho. Another common misconception is that these exemptions were enacted under the JOBS Act. They were all, with the exception of Maine's, enacted under the intrastate exemption in Section 3(a)(11) of the Securities Act of 1933, which is a statutory exemption from federal registration. This exemption allows the company issuing securities (the issuer) to sell to unaccredited investors, who lack certain net worth standards, yet it requires the issuer 1) to be incorporated or has its headquarter in the state where securities are offered, 2) to be conducting $80 \%$ of its business in that state, and 3) to only sell securities to residents of that state [4]. Securities are any tradable financial assets, which includes bonds, equity, and derivatives. Only Maine's exemption is enacted under Regulation D, Rule 504. This rule also allows the issuer to sell to unaccredited investors, and if the issuer complies with the state's registration requirements, they would be able to do general solicitations and free trading of shares [4]. As a matter of fact, Title III of the JOBS Act is an exemption under Section 4(a)(6) of the Securities Act of 1933 [5].

\section{B. Crowdfunding}

It is a term used to refer to capital creation through the masses on the Internet. Entrepreneurs, artists, and nonprofits would raise money through the support of many individuals on the internet who feel some affinity to their projects, businesses, or organizations and collectively contribute money to help them reach their fundraising goal [4]. It became a popular phenomenon in the past 15 years for design, filmmaking, music, and photography projects [2]. During this period, there have been multiple record-breaking campaigns that reached their goals within blazing short time. On Kickstarter, one of the companies that provide crowdfunding platforms, the list of most funded campaigns extends to multiple pages containing over 8,000 campaigns

TABLE 1: INTRASTATE CROWDFUNDING LEGISLATIONS AS OF FEBRUARY 19, 2015 ACCORDING TO A REPORT BY THE NORTH AMERICAN SECURITIES ADMINISTRATORS ASSOCIATION (NASAA). RULES BECOME EFFECTIVE THROUGH AN ADMINISTRATIVE RULING. LAWS REQUIRE A BILL THAT NEEDS TO BE VOTED ON BY THE HOUSE OR SENATE.

\begin{tabular}{|c|c|c|c|c|c|}
\hline Legislation Type & $\mathbf{2 0 1 1}$ & $\mathbf{2 0 1 2}$ & $\mathbf{2 0 1 3}$ & $\mathbf{2 0 1 4}$ & $\mathbf{2 0 1 5}$ \\
\hline Special Order & & ID & & & \\
\hline Rules - effective & KS, GA & & & DC, TX, VT & MR, MA, OR \\
\hline Law - effective & & & MI & AL, WA, WI, IN, MD & TN, VA \\
\hline Rules - proposed & & & & NM & MS \\
\hline Bill (law) - introduced & & & & CT, FL, HI, IA, KY, MN, \\
NE, NH, NJ, NC, UT, WV \\
\hline
\end{tabular}


with at least 5 of them are funded over $10,000 \%$ of the original goal [6]. These huge accomplishments made crowdfunding a favorable method of capital creation among the common public. They also caused the term to be commonly used in reference to the reward-based crowdfunding. Currently, crowdfunding companies, such as Kickstarter and Indiegogo, only allow raising money by receiving donations or loans without giving funders any security interests in the project's company [7]. This is because any potential economic return could turn the transaction into a securities offering subject to the costly federal and state laws and regulations [8]. However, since the JOBS Act, the public started recognizing another type of crowdfunding, which is securities-based; raising funds for a new business by connecting aspiring entrepreneurs with potential investors [9].

\section{RESEARCH METHOD}

This paper was written based on extensive literature research conducted to confirm hypotheses learned from my experience with Oregon's intrastate crowdfunding exemption since its early stages. Although I cannot claim to be an expert on securities crowdfunding, I have been very involved in bringing securities crowdfunding to the state of Oregon. Being a member of the founding team of the exemption, I conducted the initial research on intrastate crowdfunding around the United States, which enabled Oregon's exemption to move forward. My experience also includes participation in the statewide team meetings, meetings with the state regulators, and educational meetings for Oregon's entrepreneurs. I have also led the development and management of HatchOregon.com, which is currently Oregon's only online platform that facilitates its intrastate crowdfunding. It is noteworthy that Oregon is the only state that launched its exemption with companies ready to use it. This is mostly attributed to the leadership and educational efforts of Hatch Innovation, the organization I worked with.

\section{THE COMPLEXITY}

Crowdfunding has been effective in enabling new innovations and ideas come alive. However, intrastate crowdfunding is uniquely positioned between two very popular funding mechanisms: non-securities-based crowdfunding and private equity investments. The popular success of non-securities-based crowdfunding, which includes reward, loan, and donation based crowdfunding, is dependent on the large numbers of funders and the pace the campaign gathers these funders. In contrast, the success of private equity investments is dependent on the high returns of investment that also offset its high costs. This unique position introduces complexity upon intrastate securities crowdfunding, which needs to be mitigated in order for it to be successful in the years to come. The paper will analyze this complexity by breaking it down into advantages and disadvantages. Each potential advantage and disadvantage will be discussed and recommendations will be made needed. Recommendations in this paper can help technology managers and technology entrepreneurs gain a solid background on intrastate securities crowdfunding before seeking funds through it, learn what is needed to manage a successful intrastate crowdfunding campaign, and know the key features to consider have they decided to build online platforms to facilitate intrastate securities crowdfunding. Recommendations will also be useful for organizations and agencies that plan to provide technical business services to entrepreneurs and small businesses that want to use the exemptions. Finally, the data and recommendations will provide support to advocates and regulators in updating some regulations that are affecting the success of intrastate securities crowdfunding.

\section{A. The advantages}

The common known advantage of crowdfunding, in general, is the financial amount it helps to raise. However, it is crucial to educate the public of all the other less popularly known advantages as they have been more valuable to companies than the money rose. [10]:

1. Crowdfunding has been a way to validate business ideas, especially those that are not yet worth millions of dollars. The pace in which the campaign reaches its target tells how attractive the idea is. For instance, if the campaign ends nowhere close to its target, it is a sign that the idea needs to be rethought and improved [11].

2. It has helped as a marketing tool to increase product and brand awareness as well as to recruit employees and collaborators. It is common that a company would have a proceeding campaign or even campaigns [10].

3. The advantages also extend to small business owners, who are trying hard to keep their businesses surviving or grow them. These types of businesses often face challenges in getting the financial support they need from traditional avenues, such as bank loans, private equity or venture capital firms [12]. After the 2008 financial crisis, bank loans became stricter for them and if received, it would often come with higher interest rates. Additionally, their growth potential size is not of interest for private equity and venture capital who only support a selected slice of U.S. companies [2].

Furthermore, intrastate crowdfunding has the potential of even more advantages that are often overlooked in the news:

4. The first one, and most important, is due to the regulations that limit its territory within the respective state, it keeps all local investments local. This has economical, social, and legal benefits to the state.

a. Economically, it provides the much-needed financial support to local economy by allowing locals to fund local small businesses and startups. When these businesses grow or at least stay in business, this guarantees that local jobs are not lost if not increased. 
In addition, part of the money that the small business generates will certainly be used to buy goods from another local business in the state versus money that is generated by a large out of state business will go outside the state.

b. Socially, it generates social connections between the business and locals. For example, when Joe, a local resident, becomes an investor in a local printing shop, he will instantly become more interested in the success of that shop. He will be more inclined to do his printing there, recommend it to new customers, potential partners and employees, and might even bring in more investors to support it. This interest could also be leveraged by the shop to create a social support system for the owners to survive the stress of running a business, which is not trivial.

c. Legally, it provides a clear legal framework for individuals like Joe to be able to invest in their community whereas before intrastate crowdfunding, unaccredited individuals did not have a well established framework to support a company and get returns.

5. It helps in mitigating the inevitable startup and small businesses' investment risk [2]. This is because the investor cap in intrastate crowdfunding limits individual investments in each company. This not only limits the loss, but also spreads and shares it between multiple investors if it happens. In contrast, in private equity only a handful of investors have to face the loss.

6. Some innovative projects would not have become a reality without the crowd's funds. Yet, funders could not share this success due to restricting regulations discussed previously. They only got to receive rewards that range from feeling good to support a cool idea to a preorder of the product. They have never had the chance to share a project's profit in the U.S. Now, they can actually do real investments where they can get returns based on the offer terms.

7. Last but not least, in term of loans, intrastate crowdfunding puts the entrepreneur back in control to decide on the loan terms, rates, and deal's details. This eliminates parts of the stress that restful from dealing with traditional funding avenues and helps the entrepreneur to focus on the business.

\section{B. The disadvantages}

Public misconceptions, prohibitive regulations and the large number of investors cause most of the disadvantages for intrastate securities crowdfunding. However, these disadvantages could be mitigated with either educational awareness, regulation change or the use of technology. Each category will be discussed separately:

1. Public misconceptions

a. Because intrastate securities crowdfunding deals with equity, which is also what private equity or angel investing deals with, it is often critiqued whether it can make its investors similar multiple returns on their investments. It is important to remember, however, that in angel investments, angels make multiple investments in different companies and often only get positive returns generated by about ten percent of the investments [13]. Angel investment is private equity investing made by a class of individuals with enough wealth to be considered as accredited investors. The positive returns from angel investing are large enough to offset the losses caused by the rest of angels' investments. It is known that without this small minority of winners, angel investing would not be profitable on average. Therefore, approaching intrastate crowdfunding as if it was angel investing will put it in disadvantage and will limit its previously discussed advantages. If Joe, the local investor, would invest in the print shop only because he expects returns on his investment like those expected in angel investing, he will be disappointed and will not continue investing locally. Nevertheless, this argument is not to say that intrastate crowdfunding will never make an investor multiple of returns. It is to emphasize the significance of educating the public of the differences between it and angel investing in order for the intrastate crowdfunding to succeed, especially at its early days. A better way to perceive intrastate crowdfunding is by considering the concept of local support, which makes every investment made in intrastate crowdfunding a winning investment, ultimately.

b. The other misconception is that intrastate crowdfunding is in disadvantage because it has a limited capacity for raising money [11] unlike the reward-based crowdfunding, venture capital or angel investments where companies are able to raise multiple millions of dollars. Most states allow a maximum of one million dollar per the 12-month period. Meanwhile, the Federal Reserve's Small Business Credit Survey of Fall 2013 shows that a total of $68 \%$ of small businesses applications for loans were asking for only $\$ 250,000$ or less, with $39 \%$ asking

TABLE 2: THE LIMIT ON HOW MUCH A SINGLE INVESTOR CAN INVEST IN A SINGLE OFFER ACCORDING TO EACH INTRASTATE CROWDFUNDING EXCEPTION. - NOT ALL AVAILABLE EXEMPTIONS ARE INCLUDED

\begin{tabular}{|c|c|c|c|c|c|c|}
\hline $\begin{array}{c}\text { Investor Limit per } \\
\text { offer }\end{array}$ & $\mathbf{\$ 1 0 , 0 0 0}$ & $\mathbf{\$ 5 , 0 0 0}$ & $\mathbf{\$ 2 , 5 0 0}$ & $\mathbf{\$ 1 0 0}$ & $\begin{array}{c}\mathbf{\$ 2 , 0 0 0} \text { or 5\% of } \\
\text { investor's annual income } \\
\text { if income under } \mathbf{1 0 0 , 0 0 0} \\
\text { per year }\end{array}$ & $\begin{array}{c}\mathbf{1 0 \%} \text { of an investor's annual } \\
\text { income if income over } \\
\mathbf{\$ 1 0 0 , 0 0 0} \text { per year }\end{array}$ \\
\hline States & GA, MI, WI & $\begin{array}{c}\text { KS, ME, IA, } \\
\text { AL }\end{array}$ & OR & MD & WA & WA \\
\hline
\end{tabular}


2015 Proceedings of PICMET '15: Management of the Technology Age

TABLE 3: THE LIMIT ON HOW MUCH MONEY CAN BE RAISED A SINGLE OFFER ACCORDING TO EACH INTRASTATE CROWDFUNDING EXCEPTION. - NOT ALL AVAILABLE EXEMPTIONS ARE INCLUDED

\begin{tabular}{|c|c|c|c|c|}
\hline Offering Limit & $\begin{array}{c}\mathbf{\$ 2 , 0 0 0 , 0 0 0} \text { with audited financial } \\
\text { statements }\end{array}$ & $\mathbf{\$ 1 , 0 0 0 , 0 0 0}$ & $\mathbf{\$ 2 5 0 , 0 0 0}$ & $\mathbf{\$ 1 0 0 , 0 0 0}$ \\
\hline States & MI, WI, IA & GA, KS, ME, MI, WI, IA, WA, AL & OR & MD \\
\hline
\end{tabular}

for less than $\$ 50,000[12]$. Given that small businesses generate the majority of jobs and sales in the U.S [14] while they struggle the most to get the needed financial support [12], these limits are justifiable. In addition, it is critical to remember that because of these limits in intrastate crowdfunding, states were able to lower the amount of disclosures required, which otherwise could add expensively prohibitive costs on the issuer. These costs actually could be quite large if compared with the funding goal that it would not be realistic to even do a crowdfunding. "According to estimates by the SEC, the initial cost for offerings that are trying to raise $\$ 100,000$ is estimated to be $\$ 15,000$, which is $15 \%$. If the raise goal is $\$ 500,000$, the cost $\$ 63,000(13 \%)$; $\$ 1$ million might cost $\$ 149,000$ (15\%)" [3]. These costly requirements are found in the Securities Act, the JOBS Act and the other Regulations. Therefore, it is necessary to educate the public that the limits in intrastate crowdfunding are actually in favor of the population that needs it the most. It is also necessary to educate them that the existence of intrastate crowdfunding does not eliminate other funding avenues, and entrepreneurs should choose the fund raising an avenue based on their needs. For some companies, intrastate crowdfunding is not be suitable.

c. The third misconception is the fear that using intrastate crowdfunding would result in losing confidentiality of the idea since it is shared online before the entrepreneur pioneers it [11]. This would actually be the case for any other funding avenue. The entrepreneur has to share the idea to attract funding, and especially in crowdfunding efforts, it has to be shared with a large number of potential funders. This is another reason to educate entrepreneurs on selecting the suitable funding avenue, as seeking funds from private equity might be more controllable for entrepreneurs who are worried about sharing their idea with the masses. That said, worried entrepreneurs could still do an intrastate crowdfunding and protect their ideas. They can file provisional patent applications, which according to the United States Patent and Trademark Office (USPTO) [15] will allow them to

"... file without a formal patent claim, oath or declaration, or any information disclosure (prior art) statement. A provisional application provides the means to establish an early effective filing date in a later filed nonprovisional patent application filed. It also allows the term "Patent Pending" to be applied in connection with the description of the invention"

According to the current fee listing of USPTO, the fee for this application is minimal ranging from $\$ 65$ to $\$ 260$ depending on the entity's size [16]. This provisional application for patent would provide a maximum of 12 months pendency from the date the provisional application is filed, which will give the entrepreneurs enough time to gather funds and apply for a formal patent filing. The funds could even be included as part of the funding minimum goal, which if reached in crowdfunding then the company gets access to the funds.

d. The last misconception is the fear of fraud, which has been discussed throughout the literature and is one of the reasons of SEC's delay with the JOBS Act [13], [17][19]. It could summarized by the fear that equity crowdfunding would become a fraud haven given that its investors are "less sophisticated" than angel's or venture capital's investors. Some authors suggest to increase requirements on issuers [17] while another suggested to halt the exceptions [13]. Although securities crowdfunding has been in place for 8 years in Australia and 3 years in the U.K. without any instances of fraud [20], it is imperative to educate the public why this is the case. The main reason is in crowdfunding the crowd does a lot of the due diligence. In a study of 48,500 Kickstarter projects, "less than 4 percent had even a whiff of rip-off" [21]. The reason is attributed to "Linus's Law," named after a software engineer called Linus Torvalds, who theorized: "Given enough eyeballs, all bugs are shallow." In other words, the scam is exposed when enough eyeballs look at. It is also noteworthy that fraud has happened even with "sophisticated investors" [17] as well as rewardbased and donation-based crowdfunding [21]. However, that does not necessarily mean that those avenues are fraud havens. Each of these has actually out-run its fraud with many successful projects.

\section{Prohibitive regulations}

Reward-based crowdfunding has shown that just having a campaign on the Internet is not enough to attract funders. Richard Swart, the director of research at the Program for Innovation in Entrepreneurial and Social Finance at the University of California, Berkeley says that "campaigns that successfully raised $\$ 100,000$ spent at least 200 hours preparing for a crowdfunding effort and an average of 136 hours managing it" [22]. This means that the company would need to operate by a strong solicitation plan that outlines "the day-to-day strategies for social media, posting updates and soliciting media coverage from national news outlets and popular blogs" not only during the campaign, but even before it goes live. According to Dr. Swart, "to reach the funding target, the first 30 percent of funds needs to be committed before the campaign goes live." "You need to develop relationships with thought leaders, celebrities and other supporters who will back the project and [agree to] amplify 
your message on social media before going live." "To be successful in crowdfunding, first you build a community, then you engage them" [22].

Nonetheless, the SEC has tricky communication restrictions that are imposed when any securities offering is planned or is in process. These restrictions apply to intrastate securities crowdfunding offers although communication practices nowadays and the interconnected nature of the Internet conflict with such restrictions. Subsequently, intrastate crowdfunding companies cannot perform the vital solicitation activities discussed earlier, which puts the whole financing tool into a real disadvantage.

a. According to a detailed discussion of these restrictions in a memorandum by Skadden, Arps, Slate, Meagher \& Flom LLP [23],

"The Securities Act defines an "offer" as "every attempt or offer to dispose of, or solicitations of offers to buy, a security or interest in a security for value." Courts have interpreted the definition of "offer" to include any activity that may have the effect of soliciting or creating a buying interest in a security. Violations of communications restrictions are not limited to issuers."

Since intrastate crowdfunding is restricted to only residents of the corresponding state, this broad definition makes any pitch or promotion that goes on the Internet a possible offer to someone from outside that state. As a result, the promoter, whether it was the issuer or the crowdfunding intermediary, will be out of compliance. "Even if a promoter were organized under the laws of a particular state, conducted most of its business in that state, and planned on using the money it raised in that state, it can only make offers to other residents of that state. If a promoter makes an offer to even one nonresident, then the exemption is lost" [4]. Furthermore, for the SEC, intent is not required to determine that a violation has occurred, which might result in significant consequences for the company [23]. With the interconnectivity of the Internet, it is impossible for a promoter to absolutely eliminate all possibilities that their online pitches are not seen outside of the state. In other words, other than a Web page with restricted access on their Web site, intrastate crowdfunding campaigns cannot be pitched on promoters' Web sites, social media, or blogs, and not on popular blogs, the media or even on local media if the press will be published or broadcasted on the Internet. This takes away the most vital success element from intrastate crowdfunding that reward-based crowdfunding has enjoyed for years and with it became successful.

"The policy underlying these restrictions is the concern that certain communications may condition the market or arouse public interest in a particular security without providing investors with adequate disclosure" [23]. Nevertheless, with business communication nowadays happening mostly on the Internet it is essential to update the regulations accordingly, so intrastate crowdfunding can actually harness the power of the masses. First of all, the Internet is an extremely busy medium. The "Digital Universe" is the term used to refer to the data created and copied on the Internet. Every two years its size doubles, and by 2020 its size will reach 44 zettabytes, or 44 trillion gigabytes [24]. To illustrate this, if we use iPads Air 128GB to represent this size, "there would be 6.6 stacks from the Earth to the Moon" by 2020 while in 2013 the stack would have reached "two-thirds the way to the moon". Hence, promoters need solid solicitation plans to be able to get their message across this enormous noise of data by circulating data in different length, shapes, or forms. A recommended update to the regulation is to clearly distinguish between selling, offering, and advertising as follows:

1) Advertising should not be considered offering. Currently, advertising is included as a part of offering. Yet, the advertisement of a product does not necessarily mean it is being offered. For example, in grocery stores, alcoholic beverages are advertised on shelves that are at the same eye level as minors' and even children's. This advertisement is legal while a targeted advertisement to minors such as labeling shelves "for minors" would be illegal.

2) Offering should be defined as targeted advertisements, which are usually concise and creative. Currently, the regulations do not make this distinction. A targeted advertisement should be allowed to circulate as long as it is targeted to the legal audience. For example, minors and children readily see an alcoholic beverage commercial that is broadcast on TV or the Internet, but it is targeted to adults. Therefore, it is legal and the only time evidence is required to verify age is when there is actual sale.

3) Selling should be defined as when money is exchanged. This is the most feasible stage to require full disclosers and requiring proofs to be provided. All advertisements and offers as described above online or offline must lead to this sale Web page. Before investors make any payment, they are then required to self-certify that they have read all disclosures.

This distinction and channeling of all intrastate crowdfunding investments through a Web platform will not only allow to harness the power of the crowd and ensure that adequate disclosures are provided, but also will give investors the chance to review the crowd's due diligence on the campaign's page and ultimately reduce chances of fraud as discussed earlier in the paper.

b. No communications about the offer is allowed prior to filing. This restriction conflicts with Dr. Swart's recommendation of building a community and having the first 30 percent of funds committed before the campaign goes live. However, if the recommendations discussed above were made, the issuers can work around this 
restriction by strategically timing their filing time with the sate and their time of launching the campaign. Any company interested in raising funds whether involving securities or not must actually start building its online presence from now. Issuers should prepare their solicitation plans before filing and allow for at least onemonth period between the time of filing and launching the campaign. This period is based on Dr. Swart's 200 hours of preparation for a $\$ 100,000$ crowdfunding campaign assuming that companies will work at least full-time on it. The one-month will allow them to communicate their offering, prepare their community, and launch the campaign into a successful crossing of the "investing chasm".

\section{Large investor numbers}

As defined earlier, crowdfunding is a tool to raise funds from a large number of funders. This large number of funders, or investors in the case of intrastate securities crowdfunding, will require a considerable amount of effort and time. It could easily become overwhelming for a starving startup or a small business to deal with this volume. Yet, this is where technology and software can chip in. The following is a list of tasks that an issuer using intrastate crowdfunding would need to perform. These are indeed daunting tasks for an issuer to do while hustling to manage a campaign as described previously. A closer look to each of these tasks though would reveal that there is a possible repetitiveness in the task and therefore a potential automation by technology.

1. Checking the residency of investors before making an offer. As discussed beforehand, the issuer needs to ensure that offers' information is only communicated to a resident of the prospective state. The first thought would be to use Internet Protocol (IP) addresses to block access from outside a state. However, this method is not accurate since the block could be overcome and if residents are vacationing outside their state, they will be blocked as well. A better solution is by connecting the intrastate crowdfunding platform with the department of motor vehicles' (DMV) databases through an application program interface (API). It is a software intermediary that allows other applications to interact with each other and share data. Driver data is protected by privacy guarantees, but government approved users can use the APIs. The platform would then only grant access to users with a valid local driver license number. A simpler solution is requiring users to self-certify their residency upon accessing any page on the platform.
2. Collecting investors' residency evidences. Before investors can make a payment, the issuer needs to check an evidence of their residency and keep it on record. The API solution would resolve this task as well, and a confirmation for the issuer records can be generated by the platform upon a valid verification from DMV's database. Alternatively, the intrastate crowdfunding platform can collect evidences from users as they register to he platform and automatically share these evidences with issuers when a user invests in their companies. A secure handling of evidences will be required in this case.

3. Answering all potential investors' questions. The likelihood of issuers being asked the same question multiple times is rather high. Therefore, having a questions section on the platform for each campaign is essential, similar to current reward-based crowdfunding platforms. This section would also enable the crowd's due diligence and reduce fraud as described earlier in the paper.

4. Generating certificates, receipts, or purchase documents. The issuer can create a certificate or receipt template leaving the name, address, and investment amount blank, for instance. The platform then can populate this template with investors' information and deliver a copy for each investor upon making investments.

5. Keeping investors engaged with the company's progress. To harness the full potential of intrastate crowdfunding, companies must keep their investors engaged with their progress and achievements. This task conflicts with the regulations that restrict communication as discussed earlier, but even with the presence of such restrictions, the platform can help. Issuers can showcase progress and achievements on their campaign's page, and the investors can choose to be notified with these updates or not. Since the platform access is restricted to residents, no violations are made.

6. Preparing and delivering periodic reports if required. Not all states require ongoing reporting, but for states where reporting is required the same template concept previously recommended to generate certificates can be used to generate reports. Since each report has specific contents to cover, the templates can easily be prepared and the platform can populate and deliver them on schedule. However, to avoid shifting into an advisory relationship with the issuer, it is crucial for the platform administrator to not participate in preparing any of the report's contents and only provide the means.

TABLE 4: ONGOING REPORTING REQUIREMENTS ACCORDING TO EACH INTRASTATE CROWDFUNDING EXCEPTION. REPORTS COVER BUSINESS OPERATIONS, FINANCIAL CONDITION, AND COMPENSATION TO DIRECTORS AND OFFICERS - NOT ALL AVAILABLE EXEMPTIONS ARE INCLUDED

\begin{tabular}{|c|c|c|c|}
\hline $\begin{array}{c}\text { Ongoing } \\
\text { Reports }\end{array}$ & $\begin{array}{c}\text { Quarterly reports to investors } \\
\text { and the state }\end{array}$ & Quarterly reports to investors & No requirement \\
\hline States & IN & MI, WA, WI & AL, CL, GA, ID, KS, ME, MD, \\
\hline
\end{tabular}


2015 Proceedings of PICMET '15: Management of the Technology Age

TABLE 5: COUNT OF COMPANIES FILED WITH EACH OF THEIR STATES TO DO INTRASTATE CROWDFUNDING OFFERING -

\begin{tabular}{|c|c|c|c|c|}
\hline \multicolumn{5}{|c|}{ NOT ALL STATES ARE INCLUDED DUE TO LACK OF DATA } \\
\hline Georgia: 35 & $\begin{array}{c}\text { Oregon: } 10 \\
\text { (8 currently listed) }\end{array}$ & Kansas: 8 & Indiana: 6 & Idaho: 4 \\
\hline $\begin{array}{c}\text { Alabama: } 3(1 \\
\text { approved) }\end{array}$ & Wisconsin: 2 & $\begin{array}{c}\text { Washington DC: } 2(1 \\
\text { withdrawn) }\end{array}$ & Maine: 1 & Texas \& Maryland: 0 \\
\hline
\end{tabular}

\section{CONCLUSION}

Intrastate crowdfunding might prove to be one of the most rewarding and game changing financial movements in the United States. It will strengthen the local economy represented by the majority small businesses and help launch innovative new startups. However, its unique position between non-securities-based crowdfunding and private equity investments introduces complexity that must be mitigated before rewards can be harnesses. Mitigation requires educational awareness for the common public of the overlooked advantages and unclarified misconceptions, the use of technology to automate daunting tasks caused by the large number of investors, and finally changing current communication restrictions in regulations to accommodate the interconnectivity of the Internet and the new businesses communication practices, enabling the use of the element that has been vital for crowdfunding's success.

\section{FUTURE RESEARCH}

Further research should consider contacting companies that filed with their states to do intrastate crowdfunding. A survey could be prepared based on this paper as well as exploring whether the companies actually launched their campaigns or not, and why not. It would also be key to explore how the proposed advantages and disadvantages in this paper have impacted their fund raising process. Finally, trends should be explored as well as examination of whether matrices could be developed to measure the impact of intrastate crowdfunding on the states in terms of local economy, and society resilience and strength.

\section{DISCLAIMER}

"The information in this article is provided for general informational purposes only and is not intended to be legal advice. The law changes frequently and varies from jurisdiction to jurisdiction. If you want to act on any of the information presented herein, please consult with a competent attorney licensed to practice law in your jurisdiction."

\section{REFERENCES}

[1] North American Securities Administrators Association, "Intrastate Crowdfunding Legislation," 2015.

[2] A. R. Stemler, "The JOBS Act and crowdfunding: Harnessing the power-and money-of the masses," Bus. Horiz., vol. 56, no. 3, pp. 271$275,2013$.
[3] K. Neslund, "the United States' New Crowdfunding Rules: a Pandora'S Box?," Proc. 1st Int. Sci. Conf. - Sint. 2014, pp. 31-37, 2014.

[4] E. Burkett, "A Crowdfunding Exemption? Online Investment Crowdfunding and U.S. Securities Regulation," Trans. Tennessee J. Bus., vol. 13, no. 2004, pp. 63-106, 2011.

[5] B. G. T. Davidson, J. Moloney, B. F. Brennan, and N. H. R. Dumont, "SECURITIES MARKETS SEC Proposes Rules to Implement Crowdfunding Exemption: What Factors Will Affect Its Success?," vol. 27, no. 11, pp. 2-9, 2013.

[6] Kickstarter, "Most funded projects - Kickstarter," 2014. [Online]. Available: https://www.kickstarter.com/discover/most-funded. [Accessed: 14-Mar-2015].

[7] S. Hall, D. Ljungberg, and D. Ljungberg, "Killing the Goose That Laid the Golden Eggs: How Pervasive Securities Regulation Strangles Small High Tech Medical Instrument Companies," 2014.

[8] S. R. Cohn, "The New Crowdfunding Registration Exemption: Good Idea, Bad Execution," Fla. Law Rev., vol. 64, no. 5, p. 15, 2012.

[9] Y. A. Ramsey, "What The Heck Is Crowdfunding?," Bus. People, vol. 25, no. 11, pp. 54-57, Nov. 2012.

[10] J. Alsever, "The Biggest Kick Start.," Fortune, vol. 171, no. 4, p. 46, Mar. 2015.

[11] K. Manchanda and P. Muralidharan, "Crowdfunding: A New Paradigm In Startup Financing," Glob. Conf. Bus. Financ. Proc., vol. 9, no. 1, pp. 369-374, Jan. 2014.

[12] K. G. Mills, "The State of Small Business Lending: Credit Access during the Recovery and How Technology May Change the Game," 2014.

[13] M. B. Dorff, "The Siren Call of Equity Crowdfunding.," J. Corp. Law, vol. 39, no. 3, pp. 493-524, 2014.

[14] Youreconomy.org, "YE Profile Dashboard | Explore Economic Activity In Your Community.” [Online]. Available: Youreconomy.org. [Accessed: 16-Mar-2015].

[15] USPTO, "Provisional Application for Patent." [Online]. Available: http://www.uspto.gov/patents-getting-started/patent-basics/typespatent-applications/provisional-application-patent. [Accessed: 16-Mar2015].

[16] USPTO, “USPTO Fee Schedule." [Online]. Available: http://www.uspto.gov/learning-and-resources/fees-and-payment/usptofee-schedule. [Accessed: 16-Mar-2015].

[17] E. Savitz, "Crowdfunding: Potential Legal Disaster Waiting To Happen.," Forbes.com, p. 9, Oct. 2012.

[18] V. Ryan, "Will the JOBS Act Harm Naive Investors?," CFO, vol. 29, no. 6, pp. 18-19, Jul. 2013.

[19] T. L. Hazen, "Crowdfunding Or Fraudfunding? Social Networks And The Securities Laws - Why The Specially Tailored Exemption Must Be Conditioned On Meaningful Disclosure," North Carol. Law Rev., vol. 90, pp. 1735-1769, 2012.

[20] C. Clifford, "Why Fraudsters Won't Sink Equity Crowdfunding," Entrepreneur, Apr-2014.

[21] C. Zara, "Bad Samaritans.," Newsweek Glob., vol. 161, no. 37, pp. 1-4, Oct. 2013.

[22] J. Helmer, "8 Ways To Cut Through The Crowdfunding Clutter," Entrepreneur, vol. 42, no. 6, pp. 86-90, Jun. 2014.

[23] M. \& F. L. Skadden, Arps, Slate, "Securities Offerings and Gun Jumping: What You Can and Cannot Do," Corp. Financ. Alert, no. November, 2012.

[24] EMC Corporation, "The Digital Universe of Opportunities: Rich Data and Increasing Value of the Internet of Things," 2014. 